\title{
THE IMPLEMENTATION OF TRANSITION-ACTION-DETAILS STRATEGY TO IMPROVE THE STUDENTS' WRITING ABILITY IN RECOUNT TEXT
}

\author{
Penerapan Strategi Transition-Action-Detail Untuk Meningkatkan \\ Kemampuan Menulis Teks Recount Siswa \\ Muhallim \\ English Education Department, Faculty of Teacher Training and Education \\ Muhammadiyah University of Makassar
}

\begin{abstract}
This research aimed to explain the improvement of the students' writing ability and the students' response through the implementation of "Transition-Action-Details" strategy in teaching writing. The researcher used a classroom action research principle to collect the data that consisted of two cycles. Each cycle consisted of four meetings. The findings of the research were the improvement of students' writing ability in cycle I to cycle II was $12.2 \%$, and the other side, students' participation or activeness at cycle I in the $1^{\text {st }}$ meeting was $45 \%$, $2^{\text {nd }}$ meeting $59 \%$, $3^{\text {rd }}$ meeting was $63 \%$ and $4^{\text {th }}$ meeting was $73 \%$. So the average score was $60 \%$. Where in cycle II, in the $1^{\text {st }}$ meeting was $67 \%$, $2^{\text {nd }}$ meeting was $72 \%$, $3^{\text {rd }}$ meeting was $68 \%$ and $4^{\text {th }}$ meeting was $78 \%$. There is a significant score in the average score (71.87\%). Based on the average score above, it had improvement from cycle I to cycle II (11.64\%).
\end{abstract}

Keywords: transiion-action-details strategy, recount text

The hardest part in the process of writing is how to start it. Many students have been frustrated if there are no ideas in their mind to be developed. As a result, it makes them feel thoughtless when they cannot find the right words, fear of criticism and also experienced huge confusion of having a topic and a blank paper. In addition, the school graduates do not know how to write because their school teacher fails in drilling their writing skill. To make good writing students need to go to through several steps such as prewriting, planning, writing and revising drafts, and go to final writing. It takes time to compose a piece of writing. Writing is a gradual activity involving stages like setting goals, generating ideas, organizing information, selecting appropriate language, making a draft, reading and reviewing it, than revising and editing (Peha, 2003). Therefore, students require process, practice and some steps to be able to write and become a good writer. 
Based on those reasons, variations in teaching writing are needed. The teachers should find a method, strategy, technique or effective media to encourage students' interest and to build their self confidence in writing. Lynne (2001) admits that students' interest is one of the main factors to achieve the goal of teaching learning of English. Therefore, Transition-Action-Detail Strategy is used as a media to help the teacher increase students' motivation in learning writing. Julie Bumgardner (2011) states that Transition-Actions-Details is the best strategy when you need to convey information in a particular order. Intro part (transition), main part ( action) and an add-on part or two (details). Brown (1987) considers that in teaching learning process there are three kinds of media namely audio, visual, and audio-visual. Moreover, Transition-Action-Detail Strategy is one of visual kinds that can be used in teaching writing recount text.

Related to recount writing, in applying Transition-Action-Details (TAD) is a strategy which very useful and helpful to clarify concepts and ideas. This strategy will help the students learn to be specific. Transition-Action-Details (TAD) uses a chart to help students brainstorm their ideas. It means in TAD, teacher provide a helpful tool or scaffolding.

\section{Definition of Transition-Action-Details Strategy}

Everyone recount something that happened to them, tell a friend about a movie, or maybe in school they have to retell part of story they read. Sometimes they even have to write down the steps they used to solve a problem in math. All of these things are the same in one important way because they all involve describing a sequence of events (Peha, 2003).

Julie Bumgardner (2011) states that Transition-Actions-Details is the best strategy when you need to convey information in a particular order. Intro part (transition), main part ( action) and an add-on part or two (details) .

When we describe something as a sequence of events, we can use the same basic structure every time. That structure has three parts;

a) Transitions: These are short phrases like "Then" or "After a while" or "In the beginning" that help to introduce each new action in the sequence. You don't 
have to have a transition for each action, but they can be very helpful at making your sequence flow smoothly.

b) Actions: These are the actual events (the things that happened listed in the order in which they occurred.

c) Details: This is additional information about each action. For each action, your audience will probably have two or three important questions you need to answer. These answers are your details.

Transition-Action-Details is a strategy which very useful and helpful to clarify concepts and ideas. This strategy will help the students learn to be specific. Transition-Action-Details uses a chart to help students brainstorm their ideas. It means in TAD, teacher provide a helpful tool or scaffolding.

Fournier and Graves (2002) states that scaffolding is providing support to help learners bridge the gap between what they know and can do and the intended goal. Scaffolding is one of the most effective instructional procedures. When teachers utilize scaffolding techniques in the classroom, they will cue, question, coach, corroborate, and provide basic information. If it were not for the teachers' facilitation, students would not otherwise be able to complete a task or activity by themselves.

Scaffolding is effective in achieving the level of potential development and it can be implemented for early age children. In the implementation, the teacher should well recognize the children and know properly. Scaffolding which is based on constructivism can be used by parents or teachers.(Upi Isabella,2007). Visual can be an additional for scaffolding, powerful tool to help process and link facts with events. One visual tool that has been proven to work for over thirty years is the graphic organizer, this successful strategy helps sort information and breaks it down into manageable pieces which can then be processed by passive learners. Graphic organizers clearly portray connections between main categories and subcategories that textbooks fail to establish explicitly (DiCecco and Gleason, 2002).

Graphic organizer is a way of structuring information, or arranging important aspects of a concepts or topic into a pattern using labels. Gould and Burke (1999) states that teaching writing through graphic organizer gives students 
the confidence they need to write. Supporting thisthought, says that visual organizers helps students to conceptualize, understand, and structure a piece of writing as well as provide coherence and cohesiveness.

\section{Example of Transition-Action-Details Chart}

\begin{tabular}{|c|c|c|}
\hline TRANSITION & ACTION & DETAILS \\
\hline (introduce the action) & (describe what happened) & (Answer audience questions) \\
& & \\
\hline
\end{tabular}

a. Transition column fill with the introduction for each action.

b. Action column fill with the actual events or what is happenned.

c. Details colunm fill with our answer for audience questions.

Example

\begin{tabular}{|c|l|l|}
\hline TRANSITION & \multicolumn{1}{|c|}{ ACTION } & \multicolumn{1}{c|}{ DETAILS } \\
\hline Once upon a time & $\begin{array}{l}\text { Lived a kind young prince named } \\
\text { Jonathan }\end{array}$ & $\begin{array}{l}\text { He was loved } \\
\text { He was adored by is people } \\
\text { His two close friends were Peter Piper, the servant } \\
\text { of the palace and Franklin Greedy, the son of an } \\
\text { Aristocrat. }\end{array}$ \\
\hline One Day & $\begin{array}{l}\text { The Prince, Peter Piper, and Franklin } \\
\text { Greedy were walking through the } \\
\text { forest. }\end{array}$ & $\begin{array}{l}\text { Suddenly a group of bandits attacked the three boys } \\
\text { near an old house. } \\
\text { They entered the old house and blockaded the gate } \\
\text { and doors. } \\
\text { The three boys were trapped inside the house. }\end{array}$ \\
\hline
\end{tabular}

When filling out the Transition-Action-Details chart, start in the "Action" column first. Fill in the first box with the first thing that happens. Then, go to the last "Action" box and write the end. Now, fill in everything in between. When you finish the "Action" column, add a couple of details for each action. Finally, come up with simple phrases in the "Transition" column that introduce each action.

\section{Characteristics in TAD Chart Strategy}

TAD Strategy have some characteristics as follow:

a) It uses step by step approach

In applying TAD Strategy, step by step approach is use to make the learning systematic so the composition made by the students is well structured. The TAD exercises can be published by the writing processes as follow:

1) Brainstorming: generating ideas

2) Organizing :TAD chart or other Strategies

3) Drafting: rough or first draft

4) Revising: revision of content and style 
5) Editing: editing for surface features, punctuation, spelling, capitals, etc.

\section{b) It uses graphic organizer}

Graphic organizer is a way of structuring information, or arranging important aspects of a concept or topic into a pattern using labels. The graphic that is use is in the form of TAD chart. The visual organizers help the students to conceptualize, understand, and structure a piece of written discourse successfully. It also makes the students do not feel bored.

\section{c) It fits for any composition such as: narrative and recount.}

Some level of the students are given narrative and recount text at school. TAD Chart Strategy may help them in writing the compositions. If they are able to apply the Strategy as well as possible, it is not impossible for them to improve their writing skill.

\section{Tips on Transition-Action-Details Strategy}

Tips in applying TAD Strategy, they are:

a) Testing out your sequencing. The thing it likes best about this strategy is that it lets teacher test out the story little by little so he/she can make sure it's right. Students start by filling in the first and last "Action" boxes. This way they know for sure how they want they story to start and end. Then students fill in the boxes in the middle. Finally, students read it over from top to bottom to make sure that things are in the right order and that they haven't left anything out. At this point, it's easy to make a change if they have to switch something around, add in something new, or take something out. Once the "Action" column is good, they feel confident that the rest of the story will work out well, too.

b) Filling in the details. This is just like filling in the details of an Idea-Details chart. You use the same approach, too. Look at your "Action" and then think about the questions your audience/reader would ask you about it. Or, if you like, share your writing with the class or with a partner and see what questions people ask you. The difference between the "Details" column in this strategy and the "Details" column in Idea-Details is that you don't need as many 
details for things to work out. Try to come up with two to four really good details for each action. That will usually be plenty.

c) Don't worry about the transitions. If you can't think of any transitions, or if you feel you don't need them, leave those boxes blank. First of all, not every action needs to be introduced with a transition. Second, when you start to draft, you'll probably put some transitions in naturally without thinking about it. There are only two things you have to watch out for: (1) Using the same transition over and over - that's boring. And (2) Using too many of those traditional "school" transitions like "First of all," "Another reason why...," "In conclusion," “As you can see," and so on. These transitions aren't wrong, they just sound a little strange because they're not the normal transitions most people use when they write authentically. In truth, the best writing uses no transitional phrases at all. Instead, the writer uses logic to move the reader from one action to the next.

d) The right number of actions. How many actions do you need? That's impossible to say. At a minimum, you would have to have three in order to have a beginning, a middle, and an end. There's nothing stopping you from having a hundred if you want. But most of us can only keep track of seven or so. If you have more than seven or eight actions, your story might begin to feel as though it's a bit long or too complicated. See if you can combine several actions into one. Remember, you can always expand any action into several actions at a later time (and on another chart) by using the "expand the moment" technique.

e) Working with the chart. If you have more actions in your story than there are rows on the chart, just get another piece of paper and continue. If there are more rows on the chart than you have actions in your story, just leave the ones you don't use blank. If you'd like to create extra rows on the same page, just draw a horizontal line across the chart and split any single row into two. Use the chart in whatever way makes sense to you. There's no one right way to do it. Better yet, draw your own Transition-Action-Details chart on your own paper. 


\section{Definition of Recount Text}

There are some text types taught in Junior High School, one of them is recount text. Based on the standard competencies and basic competencies, recount is taught to eight students in Junior High school.

Recount Text is a kind of text that retells past events in chronological order. The purpose of this text is to give the audience a description of what occurs and when it occurs. It is in line Gerot and Wignell (1994) explain that recount is a kind of text which has function to retell past events for the purpose of informing or entertaining. The social function of recount text is to share a story of what happened in the past.

Recount is a text which retells events or experience in the past. Its purpose is to retell events. The generic structures of recount are orientation-eventsreorientation. It has a similarity with the generic structures of narrative. The differentiated of recount text with narrative text only is in events. There is no complication in recount.

Recount text is one of the texts that recalls and reconstructs events, experiences and achievement from the past in a logical sequence. Some recounts will be purely informative, while others will aim to both inform and entertain. All recounts construct the past, but the purpose, audience and focus will vary according to the form used. Many reluctant readers or writers find this text type accessible and manageable because it is generally based on fact rather than fiction.

\section{a) Kinds of Recount Text}

The social function of recount text is to retell past events or something which is happened in the past for the purpose of informing and entertaining. There are three kinds of recount text, they are :

1) Biographical recount which are writing about what happened in the past focusing on one individual's life.

2) Historical recount is about what happened in the past focusing on a group of people who lived through a historical period. 
3) Historical recount shows and evaluates reasons why things happened in the past.

According to Derewianka (1990) classifies recount text into some types, they are :

\section{1) Personal Recount}

Telling about activities whereas the writer or speaker involves or do by her or himself (e.g. oral anecdote, diary entry) use the first pronouns (I, we). Personal responses to the events can be included, particularly at the end. Details are often chosen to add interest or humor.

2) actual Recount

Record the particulars of an incident (e.g. report of science experiment, police report, news report, historical account). A factual recount is concerned with recalling events accurately. It can range from everyday tasks such as a school accident report to a formal, structured research tasks such as a historical recount. The emphasis is on using language that is precise, factual and detailed, so that the reader gains a complete picture of the event, experience or achievement.

This type uses the third person pronouns (he, she, it, and they). Details are usually selected to help the reader reconstruct the activity or incident accurately. Sometimes the ending describes the outcomes of the activity (e.g. science experiment). Details of time, place and manner may need to be precisely stated (e.g. at 2.45 pm., between Pandawa street and Antasari street, the man drove at $90 \mathrm{~km} / \mathrm{h}$ ). The passive voice may be used (e.g. the beaker was filled with water), it may be appropriate to include explanations and justifications.

3) Imaginative Recount

Imaginative or literary recount entertain the reader by recreating the events of an imaginary world as though they are real. "A day in my life as a family pet", for example. Emotive language, specific detail and first person narration are used to give the writing impact and appeal.

4) Procedural Recount 
A procedural recount records the steps taken in completing a task or procedure. The use of technical terms, an accurate time sequence and first person narration ( I or we ), give credibility to the information provided. Example include a flow chart of the actions required for making bread, a storyboard of video tape script or advertisement, the steps taken to solve mathematical problem.

5) Biographical Recount

A biographical recount tells the story of person's life using a third person narrator (he, she, and they ). In the case of an autobiography, first person narration (I, we) is used. It is usually factually accurate and records specific names, times, place and events. A purely factual, informative biography, however, would lack the appeal provided by personal responses and memorable anecdotes. There is often an evaluation of the subject's achievements in the final section.

From five types of recount text above, the focus of the research is personal recount since it retells the activities whereas the writer or speaker involves or do by her or himself.

\section{b) Generic Structure of Recount Text}

Recount generally follow a similar structure, but the students should be guided by the purpose for an audience of their text in their use of the following structure:

\section{1) Orientation}

The orientation provides all the necessary background information to enable the audience to make sense of the text. To ensure that the orientation is detailed and thorough, use the words (who, what, when, where, and why). The writer or speaker needs to gives information about what happened, who or what was involved, when and where the events occurred and why. An awareness of audience and purpose will assist the author in selecting the amount of detailed needed.

2) Series of events 
In series of events the writer writes the events chronologically. It begins from the first event, followed by the second event to the last event. The sum of events depend on the creativity of the writer. Events should be selected carefully to add to the audience's understanding of the topic. Students should be prepared to discard events and details that are unimportant or uninteresting. A recount, in most cases, is more than a 'shopping list' of every possible detail. Students should be guided to select only those events that are relevant and that can be expanded through the inclusion of specific details.

3) Re-orientation (optional)

The final section concludes the recount by summarizing outcomes or results, evaluating the topic's importance or offering personal comment or opinion. It can also look to the future by speculating about what might happen next. But, not all of recount closed by re-orientation. It is optional.

\section{c) Language Features of Recount Text}

Language features that are used in Recount text are:

1) Simple past tense is used in most recounts, but present tense may be used to create immediacy. For example in diary or journal. Future tense is sometimes used in the conclusion of an imaginative or biographical recount to predict what might happen in the future, for example, "This great tennis player will no doubt win many more tournaments".

2) Subject-specific terms (larvae, topography) are used to record facts and events accurately. They also add authenticity and credibility to the tone of the writing.

3) Specific descriptive words (adjectives) help the audience visualize or imagine events. For example, “The butterfly spread out its limp, wet wings to dry". In a factual recount or accident report, adjective provide necessary detail for an accurate recount.

4) A range of conjunctions (because, although, while) is used to link clauses within sentences.

5) Time connectives (firstly, secondly, next, finally) are used to link separate events or paragraphs into a cohesive whole text. 
6) Passive voice is used, particularly in factual recounts, to give objectivity to the text. For example, "The land was worked by the peasants from sunrise to sunset.

7) Adverbs (yesterday, outside) and adverbial phrases. For example, 'In 1991, in top of the hotel', are used to indicate specific times and places.

8) Specific participants (nouns and pronouns, such as Mt Stromlo Observatory, William Wallace0 provide detail and credibility.

\section{RESEARCH METHODOLOGY}

\section{A. Research Design}

This research used a classroom action research design (CAR). In this Classroom Action Research (CAR), the observer used the CAR principle to collect the data. The research was divided into two cycles with each cycle consists of four phases; Planning, Action, Observation, Reflection in each cycle. The research procedure was divided into two cycles and every cycle consists of four meetings.

\section{B. Research Subject}

This classroom action research conducted at SMPN 3 Bajeng, Gowa. The subject of this research was the eighth grade students at class VIII B in 2012/ 2013 academic year.

\section{Research Instrument}

There were instrument used namely Writing Test, Questionnaire and Observation Sheet.

\section{Writing Test}

Test aimed to get information about students' improvement after teaching learning process ended. The researcher used writing test to asses and examine the students' achievement. The researcher gave test in each cycle to find out how was the students' improvement in writing recount text viewed from its content and organization. The tests were given in the last meeting of each cycle.

\section{Observation Sheet}

Observation Sheet aimed to get information the situation and students' participation of teaching and learning process. 
The researcher way to give score result of the students test would be classified into five levels as follows:

Table Scoring rubrics of Writing

\section{a. Content}

\begin{tabular}{|c|c|c|}
\hline Score & Classification & Criteria \\
\hline 5 & Excellent & $\begin{array}{l}\text { - Events, actions or ideas are creative and consistent with the context } \\
\text { established by the writer. } \\
\text {-Details are precise and consistently effective. } \\
\text {-The writing is confident, holds the reader interest. }\end{array}$ \\
\hline 4 & Proficient & $\begin{array}{l}\text {-Events, actions or ideas are intentionally chosen and are appropriate for } \\
\text { the context established by the writer. } \\
\text {-Details are specific and usually effective. } \\
\text {-The writing is purposeful, draws the reader interest. }\end{array}$ \\
\hline 3 & Satisfactory & $\begin{array}{l}\text {-Events, actions or ideas are generally appropriate for the context } \\
\text { established by the writer. } \\
\text {-Details are general and may be predictable but are appropriate. } \\
\text {-The writing is straight forward and generally holds the readers' interest . }\end{array}$ \\
\hline 2 & Limited & $\begin{array}{l}\text {-Events, actions or ideas are vague and may not be appropriate for the } \\
\text { context established by the writer. } \\
\text {-Details are view and may be repetitive. } \\
\text {-The writing is ambiguous, it does not hold the reader interest. }\end{array}$ \\
\hline 1 & Poor & $\begin{array}{l}\text {-Events, actions, or ideas are undeveloped. } \\
\text {-Details are scant. } \\
\text {-The writing is confusing or frustrating the reader. }\end{array}$ \\
\hline
\end{tabular}

\section{b. Organization}

\begin{tabular}{|c|c|c|}
\hline Score & Classification & Criteria \\
\hline 5 & Excellent & $\begin{array}{l}\text { - The beginning is purposeful and effectively established events, characters, } \\
\text { or setting and provides direction for the writing. } \\
\text {-Connections between events, actions, details or characters are developed } \\
\text {-The ending effectively ties events or actions together. }\end{array}$ \\
\hline 4 & Proficient & $\begin{array}{l}\text { - The beginning clearly established events, character or setting. } \\
\text { - Connections between events, actions, details or characters are usually } \\
\text { maintained. } \\
\text { - The ending clearly provides and appropriate finish for events or actions.. }\end{array}$ \\
\hline 3 & Satisfactory & $\begin{array}{l}\text {-The beginning directly presents information about events, character or } \\
\text { setting. } \\
\text { - Connections between events, actions, details or characters are generally } \\
\text { maintained. } \\
\text {-The ending is predictable or may be contrived but is connected to events } \\
\text { or actions. }\end{array}$ \\
\hline 2 & Limited & $\begin{array}{l}\text {-The beginning presents information about events, character or setting. } \\
\text { - Connections between events, actions, details are unclear, character are } \\
\text { missing. } \\
\text { - The ending if present is unconnected to the events or actions. predictable } \\
\text { or may be contrived but is connected to events or actions. }\end{array}$ \\
\hline 1 & Poor & $\begin{array}{l}\text {-The beginning provide little information, or is ineffective. } \\
\text {-Connections between events, actions and character are missing. } \\
\text {-The ending, if present, is unconnected to the events or actions. }\end{array}$ \\
\hline
\end{tabular}

(Julia Lee, 2009)

\section{Data Collection}

1. Data source: The data source in this research was the eighth grade students of SMPN 3 Bajeng.

2. The way in taking data. 
- Data learning outcomes obtained through the final test cycle.

- Data of students' responses obtained through the final test by using questionnaire.

- Data on teaching and learning situation obtained during the action learning process by using the observation sheet.

- Data about the reflection and the changes that occurred in the classroom was taken from the implementation of action through the notes.

The researcher used writing test to asses and examine the students' achievement. The researcher gave test in each cycle to find out how was the students' improvement in writing recount text and effectiveness of implementation of Transition-Action-Details strategy.

\section{E. Data Analysis}

The data were got from cycle I and cycle II are analyzed through the following step:

1) Calculating the mean score of the students' writing test by using the following formula:

$$
\bar{X}=\frac{\sum X}{N}
$$

Note: $\bar{X} \quad=$ Mean score

$\sum X=$ Total score

$\boldsymbol{N} \quad=\quad$ The total number of students. (Gay , 1998 )

2) To know development of the students' writing ability, the researcher use percentage technique.

$$
P=\frac{X_{2}-X_{1}}{X_{1}} \times 100
$$

Where:

$$
\begin{array}{ll}
\mathrm{P} & \text { : percentage of the students } \\
\mathrm{X}_{1} & \text { : the first mean score }
\end{array}
$$


$\mathrm{X}_{2} \quad$ : the second mean score

(Gay 1981)

\section{FINDINGS AND DISCUSSION}

\section{A. Findings}

The findings of classroom action research dealing with the answer of the problem statement which aims to improve students' achievement in writing recount text. The findings consist of students' achievement in writing and observation result. It's about the students' activeness in teaching and learning process. To measure the students' achievement of their writing result there are two components of writing that is concerned by the researcher, namely: content and organization.

There are activities that have been conducted before finding the results of the research. The activities are such as the teacher explained how to fill out TAD chart, then the students filled out TAD chart with their ideas start from first column until the last column. Finally the students can connecting all their ideas to be a good recount text.

After guide the steps in practice writing recount text, the researcher give score to the students based on their writing test result. In assessing the students' progression during learning writing material using TAD, the researcher use writing assessment of good writing from Julia Lee(2009) and the data from cycle I and cycle II is analyze through calculate the gain score is multiply with standard score (100) divided with maximal score in each component in writing. The result is the students' score. For mean score, the researcher calculates the sum of all score divide with the number of students.

\section{The Improvement of the Students' Writing Ability}

The implementation of "Transition-Action-Details" strategy to improve the students' ability in recount text can be seen in the following table and graphic:

Table 1. The Improvement of the Students' Writing Ability

\begin{tabular}{|l|c|c|}
\hline \multirow{2}{*}{ Indicators } & \multicolumn{2}{|c|}{ The students' score } \\
\cline { 2 - 3 } & Cycle I & Cycle II \\
\hline Content & 57.8 & 70 \\
\hline Organization & 60 & 72.2 \\
\hline \multicolumn{1}{|c|}{$\mathbf{X}$} & 58.8 & 71 \\
\hline
\end{tabular}


The table above indicates that there is improvement of the students' writing ability from cycle I to cycle II viewed from its content and organization. The students' mean score achievement from cycle I to cycle II is $12.2 \%$. This is the significant movement that can be example to apply this strategy.

Chart 1 . The improvement of students' writing ability

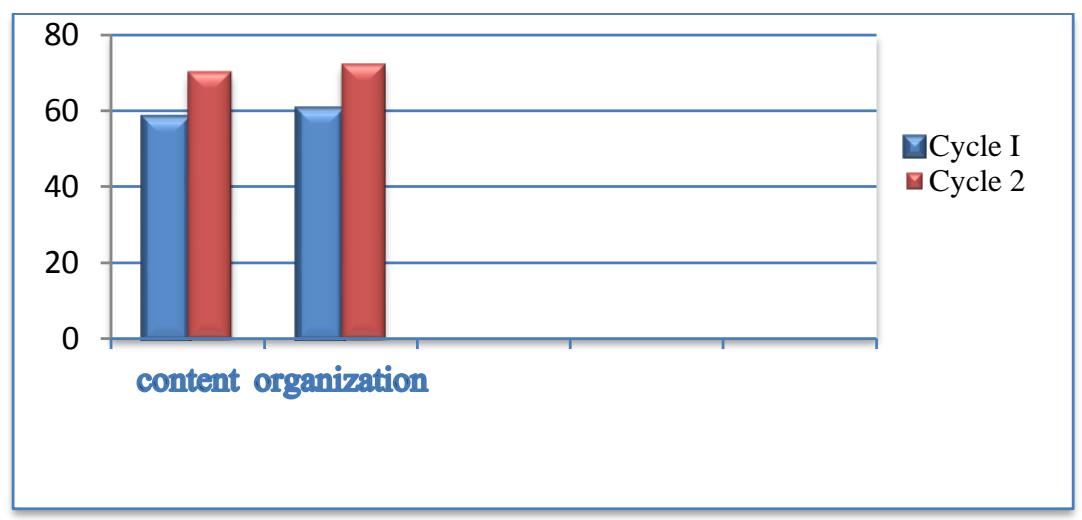

The chart above shows the improvement of the students' writing ability viewed from its content and organization from cycle I to cycle II. The improvement of students' in cycle II is higher than cycle I.

2. The Improvement of students' activeness in learning process Table 2. The observation result of the students' activeness in learning process.

\begin{tabular}{|c|c|c|c|c|c|}
\hline \multirow{2}{*}{ Cycle } & \multicolumn{4}{|c|}{ Meetings } & Average \\
\cline { 2 - 6 } & $\mathbf{1}^{\text {st }}$ & $\mathbf{2}^{\text {nd }}$ & $\mathbf{3}^{\text {rd }}$ & $\mathbf{4}^{\text {th }}$ & Score \\
\hline I & $45.13 \%$ & $59.02 \%$ & $63.88 \%$ & $72.91 \%$ & $\mathbf{6 0 . 2 3 \%}$ \\
\hline II & $67.36 \%$ & $72.91 \%$ & $68.75 \%$ & $78.47 \%$ & $\mathbf{7 1 . 8 7 \%}$ \\
\hline
\end{tabular}

Chart 2. The improvement of Students' activeness

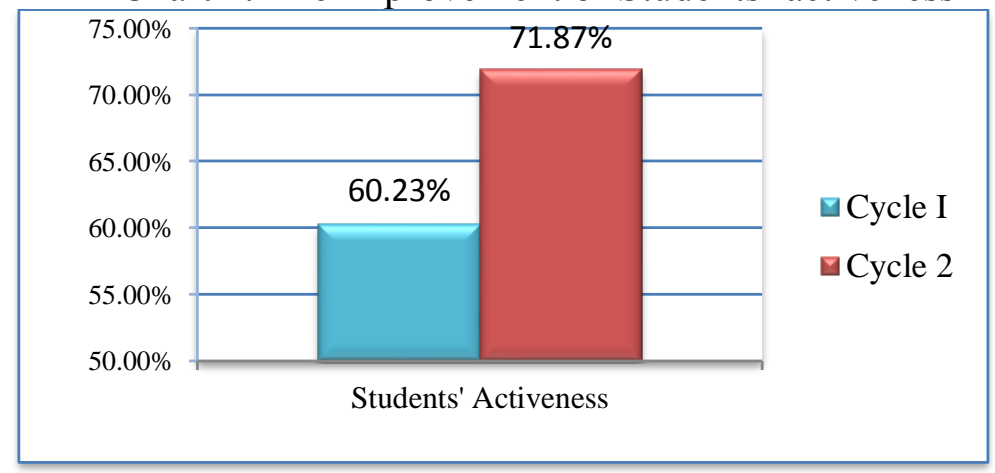

The chart above shows that the students' activeness in cycle I is lower than the students' activeness in cycle II. It is because in cycle I,TAD strategy is unfamiliar to them. They are still did not know that strategy's steps and purposes. 
The researcher also limited the students chance to write intensively. Therefore, the students are not interested in learning because they didn't enjoy the material. As result they are less active to participate in learning and teaching process. But in cycle II the researcher tried to give clearer instruction to students about TAD strategy. As result, the students became accustom with it. They get many ideas to write intensively, so during this cycle they became more active than previous cycle. Through the chart above, the researcher concludes that the implementation of Transition-Action-Details strategy can improve the students' activeness in learning writing.

\section{B. Discussion}

In this part, discussion deals with the interpretation of findings derived from the result of findings about the observation result of the students' activeness in teaching and learning process, the students' writing ability dealing with content and organization of recount text through "Transition-Action-Details" strategy.

\section{The result of the students' improvement in writing ability}

The result of the data analysis through the writing test shows that the students' writing ability in terms in content and organization improved significantly. It is indicated by the percentage of the result of the students' writing test in cycle I and II that the mean score of the students' writing test in cycle I was 58.8 (Fifty eight point eight), it is lower than the score of students' writing test in cycle II was 71 (seventy one ). These scores are got from writing test in term of content and organization of recount text. So the implementation of "TransitionAction-Details" strategy improved writing ability of students.

a. Content

The implementation of Transition-Action-Details strategy can improve the students' writing content. The table 1 indicates that the improvement of the students' writing content in cycle II is greater than cycle I. The students' mean 
score improved from 57.8 become 70 . The process that can be explained from cycle 1 to cycle 2 as follows:

At the beginning of the implementation of the first cycle has not been suitable with planning yet, this matter is caused by:

1. The Students are poorly described incomplete information to gain the aim in their writing.

2. The Students are difficult to think creatively and develop thoughts, excluding all irrelevant information.

Therefore, most of them are difficult to write clearly and still felt difficult to think creatively. As result, the mean score of the students' content in cycle 1 is still low. As we can see in table 1 that the mean score is only 57.8.This result is still under the completeness grade standard in SMP.

At the end of the second cycle can be concluded:

1. Students already wrote well describe, give the readers very clear information.

2. Students can think creatively, so they can understand what the messages convey.

The explanation above explains that, when the researcher conducted action in cycle II, the students' mean score improve from 57.8 to 70 . It has achieved the standard score in SMP. In this cycle, the researcher intensively interested the students to write. The researcher help the student's in improving their writing content.

\section{b. Organization}

The implementation of Transition-Action-Details strategy can improve the students' writing organization. The table 1 indicates that the improvement of the students' writing organization in cycle II is greater than cycle I. The students' mean score improve from 60 become 72 . The process that can be explained from cycle 1 to cycle 2 as follows: 
At the beginning of the implementation of the first cycle has not been suitable with planning yet, this matter is caused by:

1. The Students are low ideas and topic which relevant in a topic.

2. The Students are cannot understand what they write because their writing did not organize.

Therefore, most of them are low ideas and they can't understand what they write. As result, the mean score of the students' organization in cycle 1 is still low. As we can see in table 1 that the mean score is only 60. Its result is still under the completeness grade standard in SMP.

At the end of the second cycle can be concluded:

1. Students already developed ideas and topic which relevant in a united form.

2. Students can arrange and organize the ideas or messages in writing.

The explanation above explains that, when the researcher conducted action in cycle II, the students' mean score improve from 60 to 72 . It has achieved the standard score in SMP. In this cycle, the researcher intensively interested the students to write. The researcher helps the students' in improving their writing organization.

\section{The result of the students' activeness in learning process}

The observation in the cycle I and II, the teacher making note to the all activities of the students in every meetings, so the teacher can measure the improvement of the students' writing skill dealing with content and organization. Then, the teacher identity and making note all the problem that we need when teaching and learning process on observation paper and the students doing the evaluation which use the result of the study to know how far their improvement after the implementation of Transition-Action-Details strategy.

The result based on data analysis that happened in teaching and learning process, the students' activeness in cycle I is lower than the students' activeness in 
cycle II. It because in cycle I,TAD strategy is unfamiliar to them. They are still did not know that strategy's steps and purposes. The researcher also limited the students chance to write intensively. Therefore, the students are not interested in learning because they didn't enjoy the material. As result they are less active to participate in learning and teaching process. But in cycle II the researcher tried again to give clearer instruction to students about TAD strategy. As result, the students became accustom with it. They get many ideas to write intensively, so during this cycle they became more active than previous cycle. Through the chart above, the researcher concludes that the implementation of Transition-ActionDetails strategy can improve the students' activeness in learning writing.

\section{CONCLUSION AND SUGGESTION}

In this chapter, the writer would like to give several conclusion and suggestion based on the previous chapter:

\section{A. Conclusion}

1. The result of the students' writing ability

The result from data analysis through the writing test to shows writing ability achievement that the students' writing ability in terms of content and organization improved significantly. The implementation of Transition-ActionDetails Strategy can increase the students' ability to write recount text because this strategy is making different way in composing the process in teaching and learning. TAD strategy have good effect because this strategy made the students' more active to arrange their thought.

2. The result of students' activeness in learning process

These result based on data analysis that happened in teaching and learning process, the activeness in learning listening have good scores or percentages. The observation result of students' activeness in learning process, where in cycle I have average is $60.23 \%$ at the first until fourth meetings and cycle II has average 
is $71.87 \%$ at the first until fourth meetings. So based on the data above, the students activeness could improve through "Transition-Action-Details" strategy.

It proves that the implementation of "Transition-Action-Details" strategy could significantly improve the students' writing ability terms of activeness at the first students of SMP Negeri 3 Bajeng.

\section{B. Suggestions}

In relation to the writing ability in term students' response and writing ability in recount text, the writer would like to give some suggestions to students (learners), the English teachers and the next researchers as follows:

\section{For students}

a. In relation to this strategy, to get writing ability and motivation, the students should practice their English more by applying "TransitionAction-Details" strategy in every times when the students learn writing because it can stimulate them to be active and diligent to learn especially in writing. As we know that, "Transition-Action-Details" strategy has many features that we can use and then can be interesting for students to learn writing.

b. The students should be more active in learning process because writing ability needs big attention and motivation. Always spirit in every time when learning process especially in writing.

\section{For teachers of English}

a. The implementation of "Transition-Action-Details" strategy could significantly improve the students' writing ability in terms of students' response and writing recount text dealing with generic structure at the eighth grade students of SMP Negeri 3 Bajeng. So it is strongly suggested to be applied in teaching English Writing in the classroom in order to improve the students' achievement. 
b. The teachers would be more creative in teaching English especially writing because to master it need more method and strategy in improving it.

3. For the next researchers

To improve the students' writing ability generally, there are many points which should improve such as: preparation for teaching, methods, strategy, media, and ways in teaching. At this research, the writer want to know the improvement of students' writing ability through strategy that namely "Transition-ActionDetails" strategy and followed by the students' response to know the motivation and activeness of students in teaching and learning process. So for the next researcher, they can take the other ways to be improved it either they use this strategy or other strategy. But it is better to use this strategy in order to know the students' writing ability improvement for the other skills.

\section{REFERENCES}

Adelstein, M.M.E.Pival J.G. 1980. The Writing Commitment. New York. Doc.Retrieved from (http://edutechwiki.unige.ch/en/Writing).Accessed on July 28.

Anderson, M. \& Anderson, K. (2003).Text Types in English 2. Macmillan Education Australia PTY LTD.

Bumgardner, Julie.2011. http://www.thewordfactory.com/2011/01/20/clearerdirections-better-reports.accesed on July 28.

Byrne, Donn. 1979. Teaching Writing Skill. England. Longman.

Christy, Janice. 2005. Integrating Writing into Classroom. Teaching Today. Available online in :http://www.glencoe.com/sec/teachingtoday/subject/int_writing.html. Retrieved August 10, 2012.

Derewianka, Beverly.1990. Exploring How Texts Work. Australia: Primary English Teaching Association.

DiCecco, V. M. \& Gleason, M. M. (2002) Using graphic organizers to attain relational knowledge from expository text. Journal of Learning Disabilities, 35, 306-320. 
Fournier, D.N. and Graves, M.F. (2002) Scaffolding adolescents' comprehension of short stories. Journal of Adolescent and Adult Literacy, 46(1), 30-39.

Finocchiaro, M and M. Bonomo. 1973. The Foreign Language Teacher: A Guide for Teachers. New York: Regent Publishing Company Inc.

Foong, KwahPoh. 1999. Teaching Writing : a Look at Purpose, Writing Tasks, and Implications.

G. Widdowson 1978. Learning to write: first language/second language. London.Pdf.(http://www.education.com) Accessed on July 28.

Gay, J.B. 1981. Educational Research for Analysis and Allocation, Second Edition, London : Longman

Graham and Perrin 2007 The Ability to Writing. New York: Longman Group UK Limited.

Hornby. 1974. Definition of Writing. Teaching English. Accessed on June 26 http://books.google.com/teachingenglishonline.net

Isabella, Upi. Scaffolding pada Program Pendidikan Anak Usia Dini. Jurnal Pendidikan Penabur - No.08/Th.VI/Juni 2007.

Lado, R. 1959. Language Testing: The Construction and Use of Foreign Language Tests. London: Longman Group United.

Lee, Julia.2009..English Language Art Grade 3.Available at: //education.alberta.ca/media/1103067/ela3.pdf.accesed on November 2012.

Linderman, E. 1983. A Rhetoric for Writing Teachers. New York: Oxford University Press.

Oshima, Alice and Hogue, Ann. 1997. Introduction to Academic Writing. London and New York: Longman Group UK Limited.

Peha, $\quad$ Steve. $2003 . \quad$ Writing Strategy Guide. http://www.ttms.org/teachingthatmakessense

Raimes, A. 1983. Techniques in Teaching Writing. New York: Oxford University Press.

Tarigan, G 1987. Menulis Sebagai Suatu Keterampilan Berbahasa. Bandung: Angkasa. 
Troyka. 1987. Definition of Writing. Teaching English. Accessed on June 26 http://books.google.com/teachingenglishonline.net

Wallace, Truddy, E.Stariha, Winifred \& J.Walberg ,Herbert. 2004. Teaching Speaking, Listening, and writing. Accessed on August 30. http://www.ibe.unesco.org. 